\title{
Anthropogenic Impacts on Land Use and Land Cover Change in Ombeyi wetland, Kisumu County, Kenya
}

\author{
Odhiambo Nicodemus Osoro (Correspondence) \\ Department of Environmental Science and Education \\ Kenyatta University, Kenya \\ E-mail: osorodemus@gmail.com \\ Paul Obade \\ Department of Environmental Science and Education \\ Kenyatta University, Kenya \\ E-mail: obade.paul@ku.ac.ke \\ Gladys Gathuru \\ Department of Environmental Science and Education \\ Kenyatta University, Kenya \\ E-mail: gathuru.gladys@ku.ac.ke
}

Received: July 10, 2019

Accepted: August 1, 2019 Published: August 18, 2019

doi:10.5296/ijrd.v6i1.15292ＵRL: http://dx.doi.org/10.5296/ijrd.v6i1.15292

\begin{abstract}
Land use and land cover change as a result of human-induced transitions is a major environmental challenge in Lake Victoria Basin. The study adopted a mixed-method consisting of remote sensing and GIS-based analysis, key informant interviews, and household survey consisting of 384 households to asses Land Use and Land Cover Dynamics and associated human-induced transformations in Ombeyi wetland. The study aimed at generating a characterized area estimate of Ombeyi wetlands land use and land cover change schema for the study period (1990-2017), and examining the spatial and temporal characteristics of anthropogenic impacts and their relationship with land use and land cover change in Ombeyi wetland. The gis-based analysis revealed that built-up area/settlements and
\end{abstract}


agricultural lands extensively increased in area at the expense of wetland vegetation. Key informants attributed the changes to population increase $(29.2 \%)$ and an associated demand for land and natural resources as the major driving forces for the changes. Analysis of household-survey results validated the observed patterns during the remotely sensed data analysis phase of the research, as $90.1 \%(n=384)$ of the respondents reported to own land within the wetland through inheritance. $92.2 \%$ of the respondents are farmers practicing farming in the wetland with $72.4 \%$ of the same respondents attaining primary level education and below. Poverty and education levels were significant factors in influencing unsustainable land use and land cover changes observed in this study. The present state of land cover and its dynamics have had negative impacts on the riparian rural livelihoods and natural resource management.

Keywords: Remote Sensing, Land Use, Land Cover, LULC change, Ombeyi wetland, Riparian rural livelihoods, GIS-based analysis

\section{Introduction}

Land use and land cover (LULC) change as a result of human-induced transitions is a major environmental challenge in the Lake Victoria basin. Land use and land cover dynamics occurring at the local scale has risen due to socio-economic impact on ecosystems at the local level (Maurice et al., 2017). These changes are reported in a broader diverse spatial and temporal associations of social, demographic, economic, institutional and environmental factors and as such, vary in scales (Masek et al., 2000; Maurice et al., 2017). These changes have far-reaching consequences on the riparian rural communities' livelihoods in the Lake Victoria basin. Likewise, most parts of Lake Victoria Basin have experienced population growth characterized by high poverty levels, low level of education, food insecurity, high unemployment levels, settlements, and agricultural expansion, therefore, are reported as contributing factors to land use and land cover change within Lake Victoria Basin (Raburu et al, 2012; Opaa et al., 2012). More research with respect to location, nature, magnitude, pattern, rate, and extent of land use and land cover dynamics is recommended in the context of Lake Victoria basin, where high population growth, poor land management strategies, poor land use policies and other unsustainable uses are prevalent (Kabumbuli and Kiwazi, 2009; Mwagore, 2002; Campbell et al., 2003).

Like most economies in Tropical Africa, Kenya's economy is heavily dependent on rain-fed agriculture then followed by other sectors. Kenya presently is the most vulnerable to climate change due to frequent exposures to droughts and floodings. These impacts are particularly important since at least 73 percent of Kenya's population depend on agriculture for their subsistence, household income, and livelihood while only 20 percent of land in Kenya is arable (Cheruto et al., 2016; Bryan et al., 2013). The Kenyan government has continuously supported policies encouraging wetland exploitation thus most agricultural activities in Kenya occur in wetlands (Kairu, 2001; Geist \& Lambin, 2001; Kinaro, 2008; Osumba et al., 2010). Likewise, the riparian rural communities' direct dependence on wetlands' resources to meet their daily requirements continue to pose a great challenge to their management resulting into overexploitation, degradation and unsustainable use (Maitima et al., 2010; Geist 
\& Lambin, 2001; Khisa et al., 2013). Large areas of wetlands in the Lake Victoria basin have been converted to farmlands and other uses. The continued wetland conversions to farmlands could lead to the collapse of the ecosystems leading to an irreparable impact to the socio-economic welfare on the majority of the riparian rural populations (Van der Knaap et al., 2002; Owino \& Ryan, 2006). Recent studies have exhibited that wetland overexploitation in Kenya is due to poor land management strategies, infrastructure development, agriculture expansion, urbanization, and population growth (Geist \& Lambin, 2001; Owino \& Ryan, 2006; Kairu, 2001; Osumba et al., 2010).

Lake Victoria basin's LULC has experienced rapid and significant transitions over the years as a result of human-environment interactions (Andere, 2016; Auma, 2012). However, fewer studies on LULC changes on wetlands particularly small wetlands have been done in Lake Victoria Basin specifically Kenya (Kinaro, 2008; Andere, 2016; Auma, 2012). Studies on LULC dynamics and associated human-induced impacts are crucial in formulating relevant sustainable natural resource management strategies and policies. Likewise, the understanding of the drivers of LULC are complicated and contentious hence further research is crucial (Geist \& Lambin, 2001; Munthali et al., 2019). Serneels and Lambin, (2001) observed that the causes of LULC change are complicated, dynamic and vary from one location to another hence various drivers are either or both location-specific and time-bound. The drivers are determined by the socio-economic and biophysical factors prevalent and operating at that specific location. Withal, it is difficult to establish through generalization LULC changes existing in a broader spatial scale and their associated human-induced transitions influencing the changes (Munthali et al., 2019). Studies relating to magnitude, rates, pattern, extent, nature, the type is necessary for forecasting future changes and in mitigating the anticipated future changes at the local, national, regional and global level (Bewket, 2002, Foley et al., 2005; Defries \& Elshleman, 2005).

Studies relating to human-induced transitions and their impacts on LULC dynamics in Ombeyi wetland is beneficial in comprehending the inter-relationships that exist between the riparian rural population and natural resources use. By understanding the human-induced transitions responsible for the changing LULC and the use of local empirical evidence on the same, relevant stakeholders can use the information in formulating intervention strategies and sustainable land use systems in the study area. Likewise, comprehension of complex interdependence between LULC changes and the riparian rural livelihood can guide in critical decision making by policymakers, planners, and other stakeholders (Munthali et al., 2019; World Bank, 2015). Withal, research on small wetlands in tropical Africa showing underlying causes of LULC dynamics using remote sensing and GIS on the landscape are very few while the spectral signatures acquired from satellite imagery for regions within the tropics exhibit minimal band dissociation capabilities amongst the various vegetation types (Wondie et al., 2011; Kindu et al., 2013; Kiggundu et al., 2017). Moreover, past studies in Lake Victoria basin have focused in detail on the ecological, biological and hydrological components (Ajwang' et al., 2016; Khisa et al., 2013; Terer et al., 2004). The study aimed at generating a characterized area estimate of Ombeyi wetlands' land use and land cover change schema for the period between 1990 and 2017 and examining the spatial and temporal characteristic of 
anthropogenic impacts and their relationship with land use and land cover change in Ombeyi wetland. The researchers have attributed the observed land use and land cover dynamics to aggregated decisions at the household level in response to policy and an institutional environment over a period of time (Li et al., 2016).

\section{Materials and Methods}

\subsection{Study Area}

Ombeyi wetland (Figure 1) is located within the floodplains of Kano between North Ombeyi and South Ombeyi wards in Kisumu County and its total area is approximately $1037 \mathrm{Ha}$ (World Bank, 2015). It lies between latitudes $00^{0} 6^{\prime} 40^{\prime \prime} \mathrm{S}-00^{0} 10^{\prime} 00^{\prime \prime} \mathrm{S}$ and longitudes $34^{0}$ 51 ' 00 " $\mathrm{E}-34^{0} 56^{\prime} 40$ " $\mathrm{E}$ with an average elevation of between $1134 \mathrm{~m}$ above sea level around the lakeshore to $1145 \mathrm{~m}$ above sea level within the floodplains. The wetland experiences bimodal rainfall pattern averaged to be $1204 \mathrm{~mm}$ annually while temperatures' within Kano flood plains range between 13 and $31{ }^{\circ} \mathrm{C}$ within the wetland. It is characterized by alluvial soil type comprising of a dark clay and clay loam color. Its hydrology is influenced by its location in Kano floodplains and includes streams and rivers originating from the highlands of Tinderet hills, Nandi escarpment, and others (Raburu et al., 2012, World Bank, 2015).

Agriculture is the major land use in Ombeyi area and accounts for most of the economic activity. Other occupational activities include fishing, trade, beekeeping, brickmaking, mat making, biotic cover plants harvesting, stone/ sand mining and pottery (Ajwang et al., 2016). These activities generate income and are the source of their livelihood.

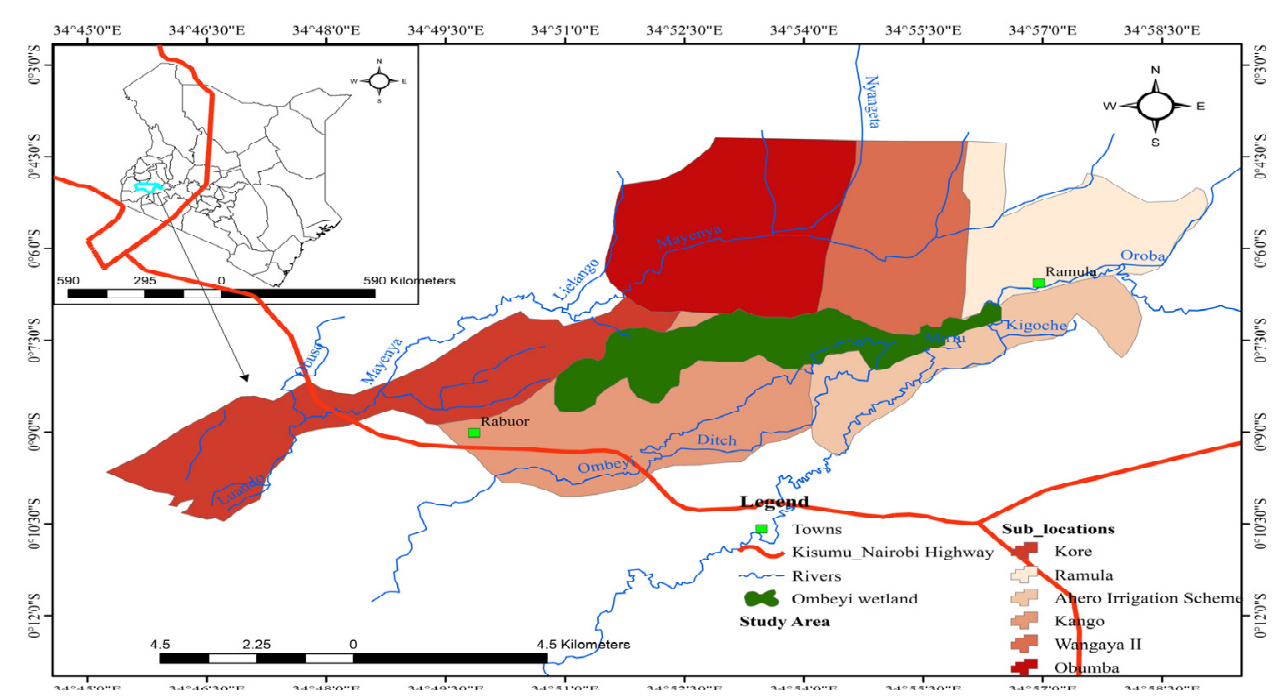

Figure 1. Ombeyi wetland area

\subsection{Data Collection}

Two types of data were used in this research. Satellite data and Primary data collected from the field using questionnaires, Key Informant Interview (KII), and direct observation including ancillary data consisting of ground truth data for the LU/LC classes. 


\subsubsection{Data Acquisition and Preprocessing}

Different remote sensing data were used in this study. The data used were Landsat images and google earth images. Four Landsat satellite images of 1990, 2000, 2010 and 2017 were acquired from the Earth Resource Observation and Science (EROS) center of United States Geological Survey (USGS) earth explorer (http://geography.usgs.gov) in raw unprocessed form. The characteristics of Landsat images used in the study are shown in Table 1. A number of factors were considered in selecting the Landsat images for the study. These include the time of the year depending on the climate of the study area, the degree of cloud cover of the selected Landsat image and the image availability for the intended year.

Satellite images pre-processing before change detection is a crucial procedure and has the distinctive objective of creating a more direct association between the biophysical phenomena on the ground and the acquired data (Coppin et al., 2004). Data were pre-processed in ERDAS imagine 2014. It included geo-referencing, mosaicking, atmospheric correction, topographic corrections, layer stacking (band selection and combination), image enhancements and subsetting (clipping) of the image on the basis of Area of interest (AOI). The four Landsat images were preprocessed for image analysis.

Table 1. Spatial datasets summary used in this study

\begin{tabular}{lllll}
\hline Sensor & $\begin{array}{l}\text { Acquisition } \\
\text { Date }\end{array}$ & Resolution(m) & Path/Row & Producer \\
Satellite data & & & & \\
Landsat TM 04 & $1990 / 02 / 07$ & $30 \mathrm{~m}$ & $170 / 060$ & USGS \\
Landsat ETM+ 07 & $2000 / 03 / 06$ & $30 \mathrm{~m}$ & $170 / 060$ & USGS \\
Landsat TM 05 & $2010 / 12 / 23$ & $30 \mathrm{~m}$ & $170 / 060$ & USGS \\
Landsat OLI/TIRS 08 & $2017 / 12 / 26$ & $30 \mathrm{~m}$ & $170 / 060$ & USGS \\
\hline
\end{tabular}

The table above describes the characteristics of various Landsat images used in the study, path, and row used to download it and its resolution $(30 \mathrm{~m})$.

\subsubsection{Image Classification and Land Use Land Cover Dynamics}

Images were classified using the hybrid classification method and it involved a combination of both supervised and unsupervised classification. Maximum likelihood supervised classification was performed for each image (Yuan et al., 2005; Manandhar et al., 2009; Prakasam et al., 2010; Rawat et al., 2013 ). A classification scheme of 4 classes was developed based on physiographical knowledge of the study area, supported by ancillary data, researchers' prior knowledge of the local area, and visual interpretation of the images. The 4 LULC classes were categorized as wetland/papyrus vegetation, agricultural land, built-up/settlements and agricultural land/farmland (Table 2). A stratified sampling method in ERDAS Imagine 2014 was employed to collect 70 points for accuracy assessment for both wetland decrease and increase classes. Google earth images were used to extract reference 
data. Accuracy assessments were determined using the kappa coefficient, overall accuracy, producer and user accuracy, which were derived from the error matrix (Congalton and Green, 2002). To continue with analysis, LULC maps were subjected to a minimum of $80 \%$ overall accuracy as recommended by Andere (2016) and Anderson (1976).

Table 2. Description of major Land use and land cover Classes

\begin{tabular}{|c|c|}
\hline Land use/land cover type & Description \\
\hline Wetland vegetation & $\begin{array}{l}\text { Permanent and seasonal grasslands along lake, river, and } \\
\text { streams, marshy land and swamps. }\end{array}$ \\
\hline Exposed bare grounds & $\begin{array}{l}\text { This class describes land without vegetation cover. This may } \\
\text { result from abandoned cropland, eroded land due to land } \\
\text { degradation and weathered road surface. }\end{array}$ \\
\hline Built-up area/Settlements & $\begin{array}{l}\text { This class describes the land covered with buildings in rural } \\
\text { and urban. It includes commercial, residential, industrial and } \\
\text { transportation infrastructures. }\end{array}$ \\
\hline Farmland/Agricultural land & $\begin{array}{l}\text { All cultivated and uncultivated agricultural lands areas, i.e. } \\
\text { farmlands, crop fields including fallow lands/plots, and } \\
\text { horticultural lands. }\end{array}$ \\
\hline
\end{tabular}

The table above gives descriptions of the major LULC classes used in the study. It gives the context in which one should perceive various land cover types in the study.

Post classification clarification is undertaken to improve classification accuracy and to reduce misclassification (Harris and Ventura, 1995). This was done concurrently with ancillary data in order to check the precision of the classified LULC map. Based on information verified on the ground, necessary correction and adjustments were made. The map from $t_{1}$ (1990) (figure 2) was compared with the map produced at time $t_{2}$ (2000) (figure 3) while $t_{2}$ (2000) was compared to $t_{3}$ (2010) (figure 4) and $t_{3}$ (2010) was compared to $t_{4}(2017)$ (figure 5) and a complete matrix of categorical change was obtained. Other LULC statistics were computed in three different ways or equations below (Modified from Kiggundu et al., 2017):

1) Total LULCC in hectare calculated by:

\section{Total LULCC - Areafual yeap Area inftial year}

Where Area refers to the extent of individual LULCC class. If the value is Positive it will signify an increase whereas if the value is negative it will suggest a decrease in extent.

2) Percentage LULCC calculated using the following equation:

$$
\text { Total LULCC }=\left(\frac{\text { Area }_{\text {Fimal year }}-\text { Area }_{\text {mattal year }}}{\text { Area }_{\text {inttlal year }}}\right) \times 100
$$

Where Area refers to the extent of each LULCC class. If the value is Positive it will signify 
an increase whereas if the value is negative it will suggest a decrease in extent.

3) The rate of LULCC: computed using the following simple formula

$$
\mathbf{R}=\frac{Q_{2}-Q_{1}}{t}
$$

Where R refers to the rate of change, Q2 refers to a recent year of LULC in Ha, Q1 refers to the initial year in LULC in ha and $t$ is the time difference between initial and recent year.

\subsection{Primary and Secondary Data Collection Tools}

\subsubsection{Household Surveys}

Semi-structured household questionnaires were used in this study. The questionnaires were comprised of both open and closed-ended questions to gather information of the socioeconomic impacts of the population and their influence on land use and land cover changes in Ombeyi area during the studied period (1990-2017). A questionnaire was preferred for this study as it provided insight into the influence of the socio-economic dynamics on LULCC in the study area (Jans et al., 2005). Mugenda and Mugenda (1999) formulae were used to determine the sample size of this research. A sample size of 384 households was derived using the formulae (Equation 4). A reconnaissance survey was undertaken before the start of fieldwork in the month of March. During the process, informal meetings and interviews were carried out with LVEMP II, Ombeyi wetland task force (WRUA) and NEMA; then, modifications were made before the actual interview of the sampled households. The questionnaires were administered to 384 households' from April 2, 2018, to May 15, 2018.

$$
u=\frac{\left(z^{2} p q\right)}{d^{2}}
$$

Where; $\mathrm{n}$ refers to the desired sample size. (Assuming the population is $>10,000$ ), $\mathrm{Z}$ is the standard normal deviation at the desired confidence level of $95 \%$ thus $1.96 . p=$ refers to the proportion in the target population that is estimated to be affected by the wetland i.e. $50 \%$. $\mathrm{q}$ $=1.0-\mathrm{p}, 1-0.5=0.50$ and $\mathrm{d}$ is the level of statistical significance set as 0.05 .

\subsubsection{Key informant interview}

Face to face interviews in the form of a key informants interview (KII) accompanied the household survey. Key informants interview were carried out to coagulate the obtained information from the household survey and gain a comprehensive understanding of nature and types of human impacts, their relationship with land use and land cover in the wetland and the measures applied to promote conservation of the wetland. A purposive sampling method was used to identify key informants based on their knowledge of the study area. In this study, key informants were one person from Lake Victoria Environmental Management Progam II (LVEMP II), two people from Ombeyi wetland management task force (WRUA) and two people from National Environmental Management Authority (NEMA) from Kisumu office because they were familiar with the issues in the study area. 


\subsection{Other Datasets}

Other data used in this study were the population estimates from the years 1989, 1999 and 2009. They were obtained from the Kenya National Bureau of Statistics (KNBS) who are the custodians of population statistics in Kenya (KNBS, 1990; KNBS, 2000; KNBS, 2010).

\subsection{Statistical Analysis}

The study used a combination of data analytical approaches and techniques. LULC change analyses were done using ArcGIS 10.4 and ERDAS imagine 2014 software. The socio-economic data derived from the questionnaire were entered, processed, coded, and analyzed using Statistical Package for Social Science (SPSS) and then subjected to further analysis. Descriptive statistics analysis was used to describe socio-economic variables of the household and how they influence LULC within the wetland. Data collected through key informants' interview were qualitatively analyzed (Hsieh and Shannon, 2005).

A non-parametric test (Pearson chi-square) was used to ascertain the differences/associations between anthropogenic impacts from increased human population and changes in land use and land cover over the study period (Lesschen et al., 2005). Paired T-test analysis was performed to identify the significant spatial and temporal change in land cover types within Ombeyi wetland as a result of land use and land cover changes over the study period (Andere, 2016; Lesschen et al., 2005). Both the independent variables for paired T-test were LULC type areas (in Ha) for the 1990 image and 2017 image.

\section{Results}

\subsection{Historical Overview of Ombeyi Wetland}

According to Key informants and Ajwang et al. (2016), Ombeyi wetland did not exist in the 1950s. At that time, there were only a few macrophytes with the most predominant being papyrus. The macrophytes were limited to the river banks forming a narrow strip along River Ombeyi. The heavy rains (Uhuru rains) experienced during 1962-1963 resulted in flooding beyond the riverbank into the floodplains enabling the macrophytes to expand landwards forming Ombeyi wetland. As a result, it affected River Ombeyi which frequently filled exceeding its banks and recurrently flooded farms and settlements around it afterward. To mitigate the periodic flooding in the area, a Japanese company (Degus) in 1984 constructed a canal. The canal diverted part of the water from River Ombeyi to the wetland in order to convey excess water away from settlement areas during rainy seasons. This situation led to the drying out of part of Ombeyi wetland and land reclamation for rice production in Ombeyi location begun. Presently, the conversion of Ombeyi wetland into rice and arrowroot farms continues unnecessarily.

\subsection{Accuracy assessments}

Accuracy assessments were performed for all supervised classified areas of images between 1990 and 2017. Historical aerial photographs from Google earth of the study area and GCPs (Ground Control Points) information collected through field excursions were important for this exercise. The overall classification accuracies were high as observed. They were $83.87 \%$ 
and $81.82 \%$ for 2017 and 2010 respectively (Table 3 and 4). User accuracies were higher hence most of the LULC were correctly labeled. The classified images Kappa index were 0.618 and 0.5217 for 2017 and 2010 respectively.

Table 3. Accuracy assessment results for the year 2017 image of land use and land cover classification

\begin{tabular}{|c|c|c|c|c|c|c|}
\hline & & Classified image & & & & \\
\hline & & Agricultural land & $\begin{array}{l}\text { Papyrus } \\
\text { Veg. }\end{array}$ & $\begin{array}{l}\text { Built-up/ } \\
\text { Settlement }\end{array}$ & Total & $\begin{array}{l}\text { Producers } \\
\text { accuracy }\end{array}$ \\
\hline & Agricultural land & 19 & 0 & 0 & 19 & $100 \%$ \\
\hline & Papyrus Veg. & 0 & 0 & 0 & 0 & 0 \\
\hline$\underset{\Xi}{\leftrightarrows}$ & Built-up/ & & & & & \\
\hline$\frac{\pi}{2}$ & Settlement & 5 & 0 & 7 & 12 & $58.33 \%$ \\
\hline ?్ల & Totals & 24 & 0 & 7 & 31 & \\
\hline อ & Users accuracy & $79.17 \%$ & 0 & $100 \%$ & & \\
\hline$\frac{\bar{e}}{2}$ & & Overall Classificati & Accuracy $=$ & $83.87 \%$ & & \\
\hline$\underline{\simeq}$ & & Overall Kappa Stat & $i c s=0.6318$ & & & \\
\hline
\end{tabular}

The table above is a specific table layout that allows one to visualize the performance of an algorithm used to compare to actual features on the ground with produced images. The table is an error matrix table of an image analyzed of 2017 using remote sensing.

Table 4. Accuracy Assessment results for the year 2010 image of land use and land cover classification

\begin{tabular}{|c|c|c|c|c|c|}
\hline & $\begin{array}{l}\text { Classified data } \\
\text { Agricultural land }\end{array}$ & $\begin{array}{l}\text { Papyrus } \\
\text { Veg. }\end{array}$ & $\begin{array}{l}\text { Built-up/ } \\
\text { Settlement }\end{array}$ & Total & $\begin{array}{l}\text { Producers } \\
\text { accuracy }\end{array}$ \\
\hline Agricultural land & 22 & 0 & 1 & 23 & $95.65 \%$ \\
\hline Papyrus Veg. & 1 & 0 & 0 & 1 & \\
\hline Built-up/Settlement & 4 & 0 & 5 & 9 & $55.56 \%$ \\
\hline Totals & 27 & 0 & 6 & 33 & \\
\hline Users accuracy & $81.48 \%$ & 0 & $83.33 \%$ & & \\
\hline & Overall Classificati & Accuracy $=$ & $81.82 \%$ & & \\
\hline & Overall Kappa Stat & $i c s=0.521$ & & & \\
\hline
\end{tabular}

The table above is a specific table layout that allows one to visualize the performance of an algorithm used to compare to actual features on the ground with produced images. The table 
is an error matrix table of an image analyzed of 2010 using remote sensing.

\subsection{Land Use and Land Cover Change Dynamics}

Table 5. Land use and land cover classes and their proportions in Ombeyi wetland

\begin{tabular}{|c|c|c|c|c|c|c|c|c|}
\hline \multicolumn{9}{|c|}{ Classified Maps } \\
\hline \multirow[b]{3}{*}{ LULC } & \multicolumn{8}{|l|}{ Years } \\
\hline & \multicolumn{2}{|l|}{1990} & \multicolumn{2}{|l|}{2000} & \multicolumn{2}{|l|}{2010} & \multicolumn{2}{|l|}{2017} \\
\hline & Ha & $\%$ & Ha & $\%$ & Ha & $\%$ & Ha & $\%$ \\
\hline Agricultural/ & 2966.5 & 73.5 & 3305.5 & 81.9 & 3261.1 & 80.8 & 3450.8 & 85.5 \\
\hline \multicolumn{9}{|l|}{ Farmland } \\
\hline Built-up/ & 52.46 & 1.3 & 528.72 & 13.1 & 762.8 & 18.9 & 581.18 & 14.4 \\
\hline \multicolumn{9}{|l|}{ Settlement } \\
\hline Wetland veg. & 1017.0 & 25.2 & 201.8 & 5 & 12.11 & 0.3 & 4.036 & 0.1 \\
\hline
\end{tabular}

The table shows the extent in Ha of various land cover types that exists in Ombeyi wetland. LULC analysis from the Landsat imagery of TM and ETM+ showed that starting from 1990 to 2000 (Fig. $2 \& 3$ ), wetland/papyrus vegetation and agricultural/cropland vegetation were the most dominant LULC types in the study area up to 2000 (Table 5) (Fig. 2 \&3). These two LULC types accounted for $3983.47 \mathrm{Ha}$ of the total area of Ombeyi wetland area in the years 1990. However, wetland/papyrus vegetation (1017 Ha) was surpassed in the year 2000 by built-up/settlements (528.72 Ha). LULC analysis from the Landsat ETM+ and OLI/TIRS imagery of 2010 and 2017 respectively (Fig. 4\&5) indicated that wetland/papyrus vegetation declined sharply to a point that it's non- existent i.e. from $12.11 \mathrm{Ha}$ in 2010 to $4.036 \mathrm{Ha}$ in 2017 (Table 5). Agriculture/farmland covered about 3261.1 Ha and $3450.8 \mathrm{Ha}$ in 2010 and 2017 respectively followed by built-up area/settlement at $762.8 \mathrm{Ha}$ and $581.18 \mathrm{Ha}$ in 2010 and 2017 respectively (Table 5). Wetland (Papyrus) vegetation showed the largest decline with a rate of decline of about $37.522 \mathrm{Ha}$ /Year for the entire study period (Fig. 6). Agriculture/farmland showed the highest increase inclining by an estimated $33.90 \mathrm{Ha} /$ Year and 27.1 Ha/Year for the years 1990-2000 and 2010-2017 respectively (Fig. 6). Built-up area increased at a rate of $19.58 \mathrm{Ha} /$ year during the study period with its largest rate at 47.63 $\mathrm{Ha} /$ year between 1990 and 2000 . 


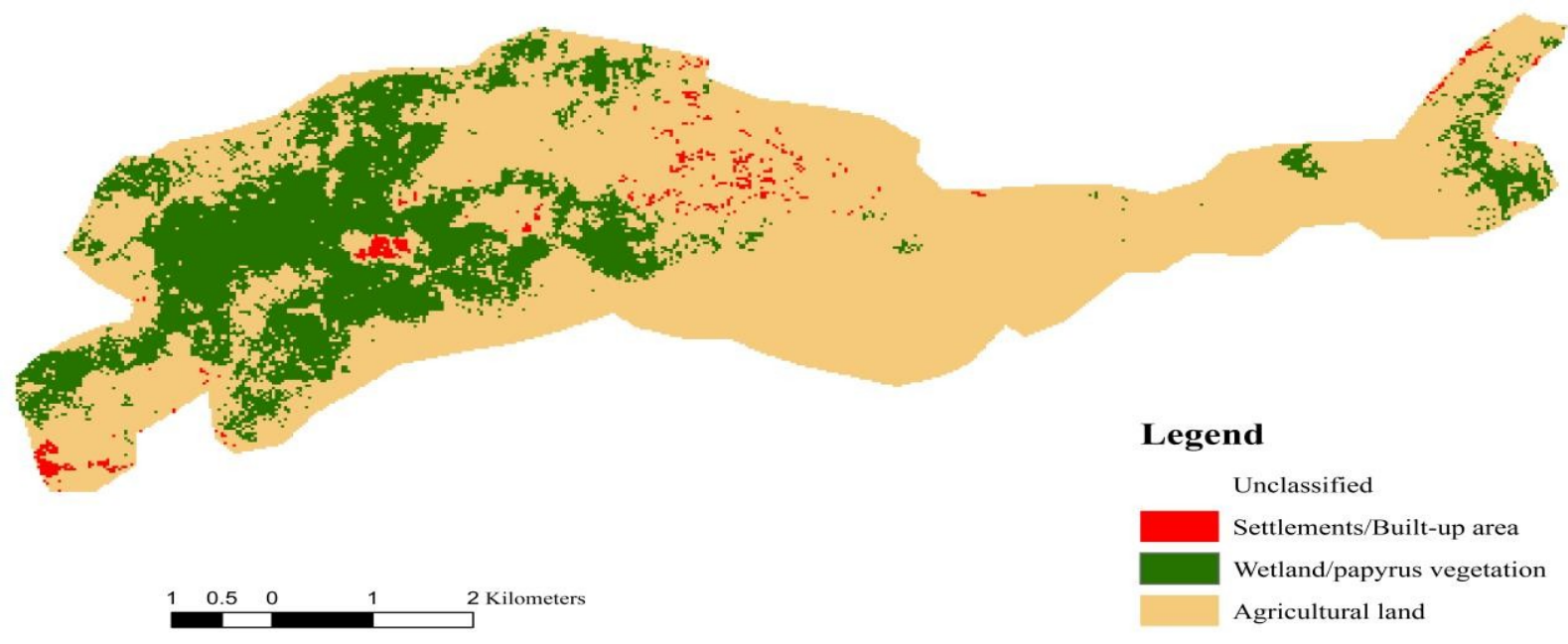

Figure 2. Land use/ cover classified map for 1990

颌

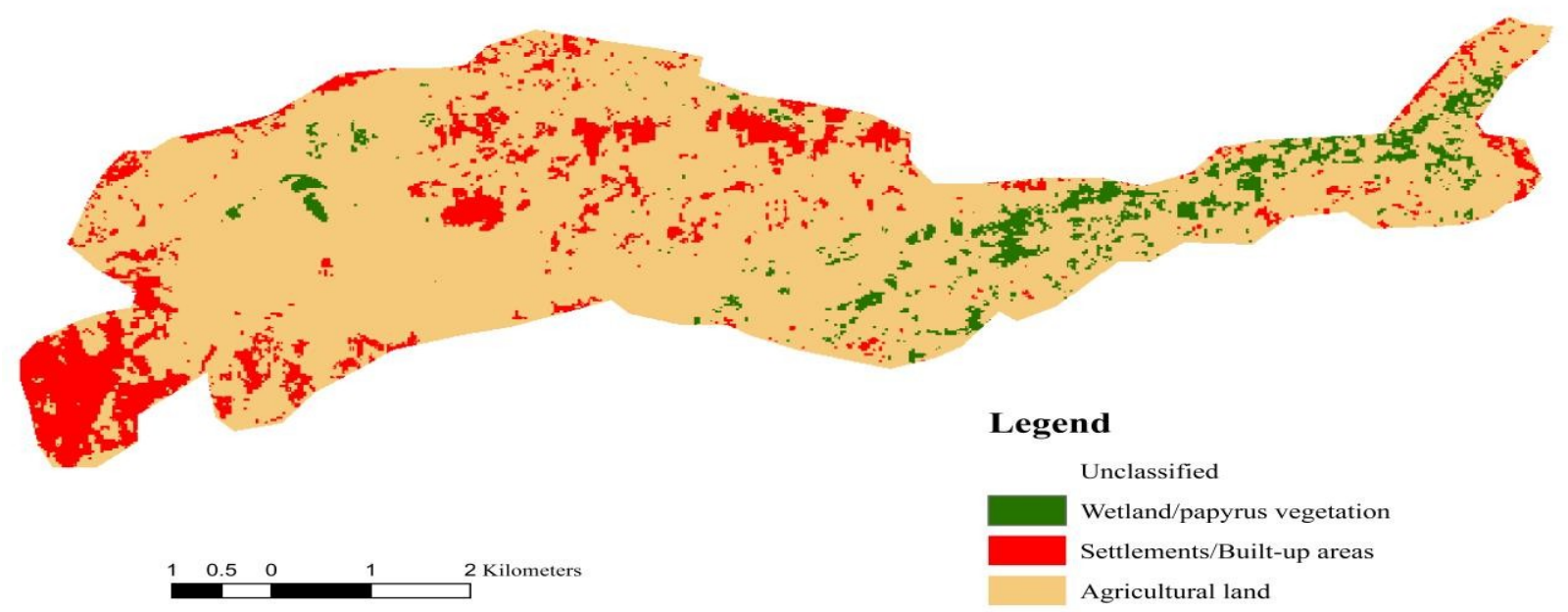

Figure 3. Land use/ cover classified map for 2000 
P

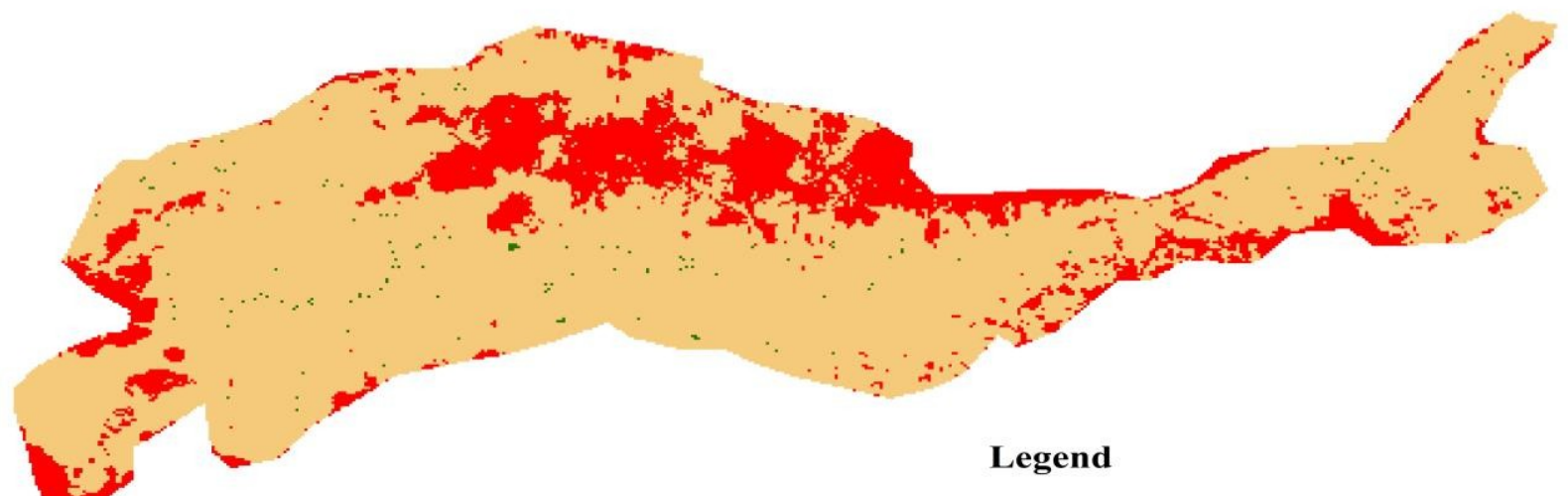

Unclassified

Agricultural lands

Wetland/papyrus vegetation

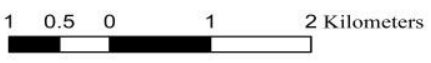

Built-up/ settlement

Figure 4. Land use/ cover classified map for 2010

粗

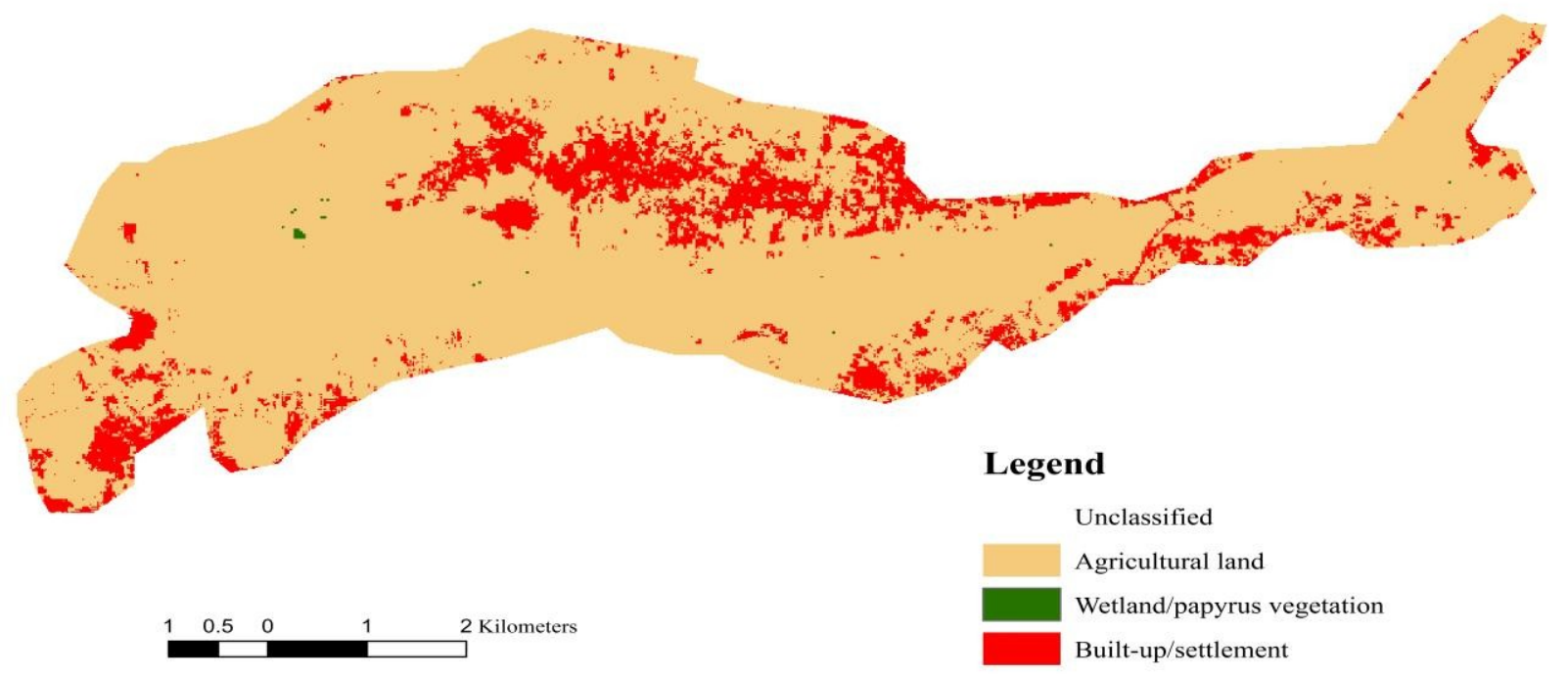

Figure 5. Land use/ cover classified map for 2017 


\section{Macrothink}

International Journal of Regional Development

ISSN 2373-9851 2019, Vol. 6, No. 1

Figure 2, 3, 4 and 5 show various images classified under maximum likelihood classification showing various proportions covered by different land cover types.

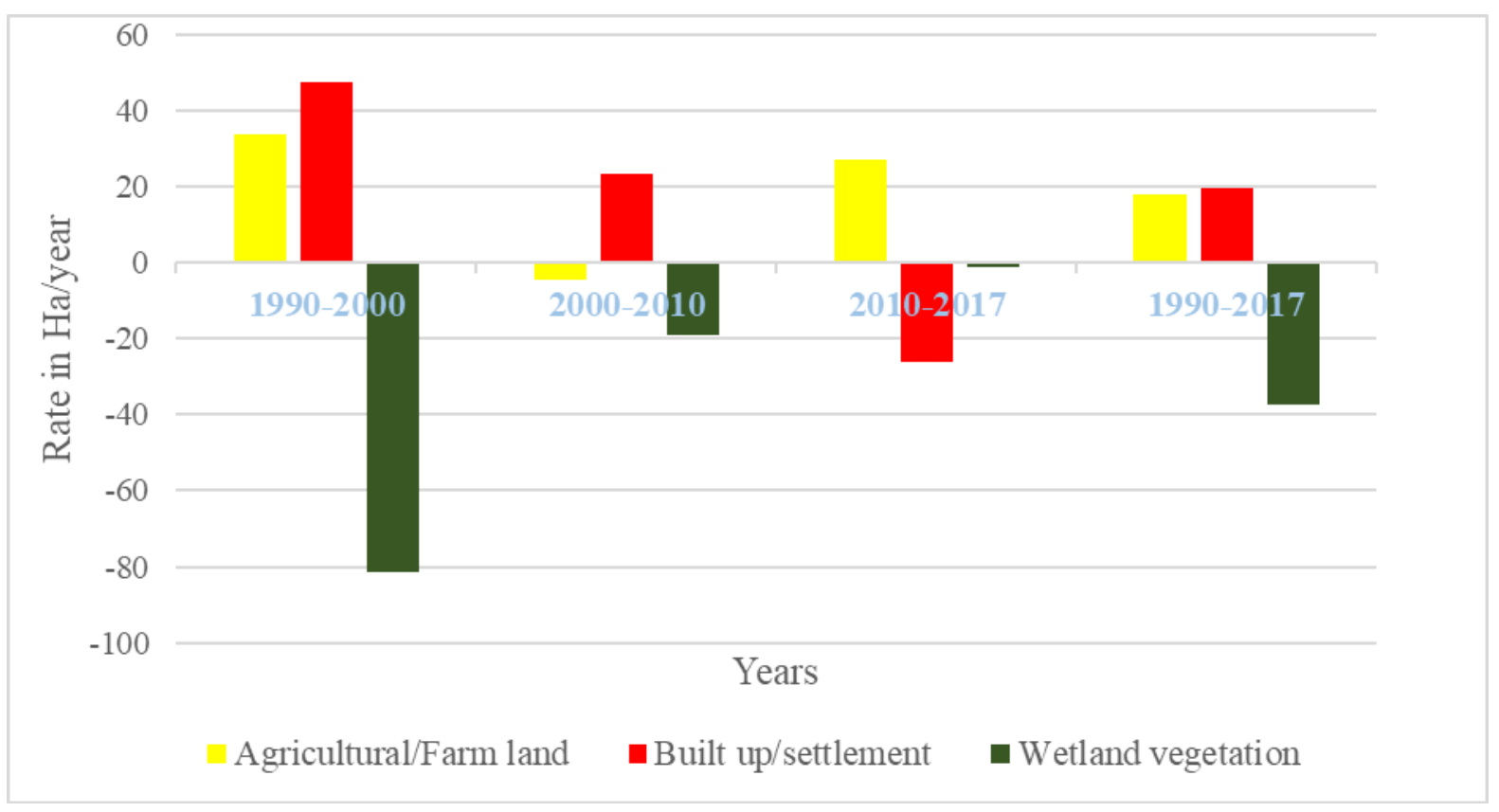

Figure 6. Rate in Ha per year change of LULC in Ombeyi wetland

The figure above shows a calculated rate per year of various land cover types that have occurred in Ombeyi wetland area over the study period.

- Paired T-test for spatial and temporal change of LULC types for 1990 and 2017

Table 6. LULCC type's significance over the study period

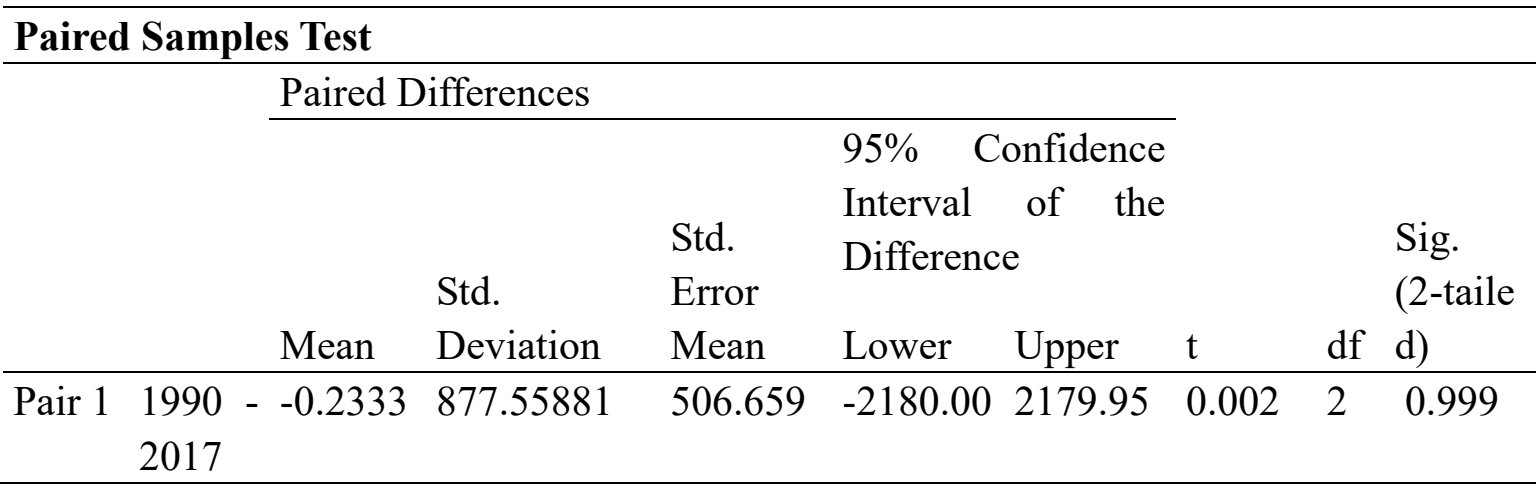

The table above shows paired t-test results for hypothesis there is significant spatial and temporal change in Ombeyi wetland's land cover types as a result of land use change over the study period. 
Significant differences were found among various LULC classes over the successive years. To ascertain that LULC classes have changed over the study period, the researcher used area covered by land uses in the year 1990 and the year 2017 as the variables (Table 5). After testing the variables, a P-value of $0.999, \mathrm{t}(2)=0.002$ (Table 6) was obtained. Because the P-value is greater than $\alpha=0.05$, the researcher accepted that there is significant spatial and temporal change in Ombeyi wetland land cover types due to land use over the study period. Similarly, Key informants attributed the LULCC in the study area to agricultural expansion, settlements, mining (sand and stone harvesting) fishing, and firewood collection as the main causes in the study area.

\subsection{Socioeconomic and Demographic Characteristics of Sampled Households}

The socioeconomic and demographic attributes of the sampled households are presented in Table 7. They were used to exhibit how they influence LULC change in the study area. It was based on household Census of 1989, 1999 and 2009 of Kenya and a household survey of the study area. Based on 1989, 1999 and 2009 household census of Kenya, the population estimates for the study area were as presented in Tables 7 (KNBS, 1990; KNBS, 2000; KNBS, 2010). However, Ombeyi wetland was previously located in Lower North East Kano location in Muhoroni division that was in Kisumu district. The locations' names and boundaries were later changed to Ombeyi location in Miwani division, Nyando district and Muhoroni become a constituency prior to 1999 census hence the renaming of the sub-locations to Table 7 below. The sub-locations population estimates were used in defining the study areas population due to the fact that they lie within the boundaries of the study area and within five kilometers from the boundary of Ombeyi wetland. Human population has increased by $29.2 \%$ (Table 7) in the study area and its environs since 1989.

Table 7. Population census of 1989, 1999 and 2009 and their respective \% change (KNBS, 1990; KNBS, 2000; KNBS, 2010)

\begin{tabular}{|c|c|c|c|c|c|c|}
\hline \multirow[t]{2}{*}{ Sub-location } & \multicolumn{6}{|c|}{ Population } \\
\hline & 1989 & $\begin{array}{l}\% \\
\text { Change }\end{array}$ & 1999 & $\begin{array}{l}\% \\
\text { Change }\end{array}$ & 2009 & $\begin{array}{l}\text { Overall \% } \\
\text { Change } \\
\text { 1989-2009 }\end{array}$ \\
\hline Obumba & 3,293 & $21.8 \%$ & 4,012 & $14 \%$ & 4,691 & 42.45 \\
\hline Ramula & 3,784 & $9.1 \%$ & 4,128 & $31 \%$ & 6,050 & 94.34 \\
\hline Kore & 4,985 & $1.7 \%$ & 5,072 & $22 \%$ & 6,551 & 31.41 \\
\hline $\begin{array}{l}\text { Ahero } \\
\text { Irrigation }\end{array}$ & 3,491 & $9.5 \%$ & 3,821 & $13 \%$ & 4,424 & 26.72 \\
\hline Kang'o & 3,113 & $27.6 \%$ & 3,973 & $13 \%$ & 4,583 & 22.41 \\
\hline Total & 18,626 & $12.8 \%$ & 21,006 & $20 \%$ & 26,307 & $29.2 \%$ \\
\hline
\end{tabular}

The table above represents the approximate population count of various sub-locations in the study area and their percentage changes. 


\section{Macrothink}

The socioeconomic attributes of the sampled households are shown in table 8 below. They revealed that about 90 percent of the interviewees lived in the study area throughout the studied period. The majority of the respondents were Females (55.2\%) and the rest were males. The respondent's age ranged from 18 to 84 years, with most of the respondents aged between 21 and 30 years (24.7\%) in Ombeyi wetland area and its environs. It is also worth noting that a larger proportion $(90.1 \%)$ of the interviewees owned land through inheritance. The farm sizes of the respondents also varied with $76.8 \%$ farming in $<2.0 \mathrm{Ha}$ or below. With respect to their education status, $72.4 \%$ of the respondents attained primary level education or below (26.6\% secondary, $1 \%$ university respectively). $92.2 \%$ of the sampled households are engaged in farming activities while a small portion of the respondents was self-employed $(4.2 \%)$ on farm-related activities, such as businesses and craftwork, and the rest were formally employed (3.6\%). The mean household income of the respondents was USD1072.9 (Kshs 107,290) per year.

Table 8. Socio-economic characteristics of respondents in Ombeyi wetland area $(n=384)$

\begin{tabular}{|c|c|}
\hline Socio-economic characteristics & Value \\
\hline Gender (Females) & $55.2 \%$ \\
\hline Age group (21-30) & $24.7 \%$ \\
\hline Level of education (Primary level and below ) & $72.4 \%$ \\
\hline Occupation (Farming) & $92.20 \%$ \\
\hline Land Holding size $(<2.0 \mathrm{Ha})$ & $76.80 \%$ \\
\hline Mean household income (USD/year) & 1072.9 \\
\hline Land ownership (Inheritance) & $90.1 \%$ \\
\hline \multicolumn{2}{|c|}{$\begin{array}{l}\text { The table above represents the respondents }(n=384) \text { socio-economic attributes from the } \\
\text { study's household survey. }\end{array}$} \\
\hline \multicolumn{2}{|l|}{ 3.5 A Non-Parametric Test (Pearson's Chi-Square) } \\
\hline \multicolumn{2}{|c|}{$\begin{array}{l}\text { Pearson's Chi-square was used by the researcher to test for a correlation between } \\
\text { anthropogenic impacts from increased human population and changes in LULC in the study } \\
\text { area. Total percentage change in population between } 1990 \text { and } 2010 \text { in Ombeyi wetland area } \\
\text { and total percentage change in various land uses within Ombeyi wetland was used as } \\
\text { variables. The result indicated that there is a strong positive correlation between } \\
\text { anthropogenic impacts from increased human population and changes in land use and land } \\
\text { cover (Table 9). The results obtained were } r \text { to be } 0.892 \text { and a P-value of } 0.3 \text {. The key } \\
\text { informants identified poverty, population growth, unreliable rainfall, high cost of agricultural } \\
\text { inputs and lack of alternative livelihood strategies as the main underlying causes of LULC } \\
\text { change in the study area. }\end{array}$} \\
\hline
\end{tabular}


Table 9. A non-parametric test (Pearson's Chi-square)

\begin{tabular}{|c|c|c|c|}
\hline \multicolumn{4}{|l|}{ Correlations } \\
\hline & & Overall \% pop. change & Overall \% LULCC \\
\hline Overall \% pop. & Pearson Correlation & 1 & .892 \\
\hline \multirow[t]{2}{*}{ Change } & Sig. (2-tailed) & & .299 \\
\hline & $\mathrm{N}$ & 5 & 3 \\
\hline Overall & Pearson Correlation & .892 & 1 \\
\hline \multirow[t]{2}{*}{ LULCC } & Sig. (2-tailed) & .299 & \\
\hline & $\mathrm{N}$ & 3 & 3 \\
\hline
\end{tabular}

The table represents a correlational test result for the hypothesis; anthropogenic impacts significantly correlate with changes in land use and land cover.

\section{Discussion}

\subsection{Land Use and Land Cover Change Dynamics}

In the period between the year 1990 and the year 2000, the land under papyrus vegetation decreased by an area of 1012.96 Ha while agriculture/farmland increased by an area of $338.94 \mathrm{Ha}$ (Table 5). This implies that the wetland vegetation was declining at the rate of 81.526 Ha per year while land under agriculture and settlement increased at a rate 33.9 Ha per year and 47.6 Ha per year over the same 10 year period respectively. Land Use and Land Cover changes are complex and interrelated such that an increase in a single or more Land Use and Land Cover class occurs at the expense of other land use and land cover classes (Shiferaw \& Singh, 2011; Tegene, 2002). Key informants linked land use and land cover changes in the study area to population growth in the area. As the population increased, the need for more houses and the demand for food increased correspondingly. This resulted in the conversion of Ombeyi wetland area to settlements and agricultural land. This clearly indicates that existing policies have supported agricultural and development activities within wetlands in Kenya thus degrading the wetland ecosystem in the process (Mwakubo \& Ikiara, 2005). This has led to the loss of the countries natural resources (Lambin \& Geist, 2001; Mwagore, 2002; Meyer \& Turner, 1994; Auma, 2012; Andere, 2016; Owino \& Ryan, 2006). Though there are laws and regulations protecting wetlands from being used indiscriminately (Swallow et al., 2003; GOK, 2014) they are continually being ignored by riparian rural populations who have no alternatives' due to socio-economic stressors leading to unsustainable use of the natural resource. Similarly, several researchers have attributed agricultural expansions in various parts of the world to be at the expense of land covered with natural vegetation (Bewket, 2002; Amsalu et al., 2007; Dessie \& Kleman, 2007; Prakasam, 2010; Schneider \& Pontius, 2001).

\subsection{Population Growth, Socioeconomic Characteristics and Their Influence on LULCC}

The research findings based on the household survey and key informant interview show that population growth has had an impact on LULCC in Ombeyi wetland. The population of the study area increased by $29.2 \%$ during the study period. The household survey and key informants suggest that the majority of residents in the study area are women who are young 
and are lowly educated with their main occupation being Farmers. These socio-economic attributes depict a community with high poverty levels and lack alternative economic sources of livelihood leading to overexploitation and unsustainable use of wetland resources. It is particularly true that in developing countries negative land use and land cover processes means loss of income (Turner et al., 2007; Jensen, 2015) and since the population in the study area is predominantly farmers, they heavily depend on the wetlands natural resources which with time have serious ramifications on food security and the socio-economic stability of the people's livelihood. Key informants established that it has led to declining or failure of crop production, soil infertility, change in rainfall pattern, overdependence and unsustainable extraction of natural resources which causes serious environmental problems. Overdependence and unsustainable use of wetland resources without alternative economic livelihood options have led to soil erosion, biodiversity loss, natural-resource depletion, water, and air pollution, disintegration, and wetland degradation (Munthali et al., 2019; Appiah et al., 2017). Similarly, the wetland is not demarcated, this situation is similar to several wetlands in tropical Africa. This, however, exposes the wetland to exploitation since it is not be protected i.e. Ramsar convention and laws governing wetlands. The wetland needs to be demarcated and zoned into various land uses and land covers hence an area set aside for conservation and an area for various land uses. This will minimize conflict that arises between conservationists and those supporting conversions thus ensuring human and ecological security (Lopez, 2002). The results of this study relate to other similar studies in Africa where poverty levels were reported as contributory factors for land use and land cover changes (Haller et al., 2008; Kindu et al., 2015; Ariti et al., 2015).

\section{Conclusions}

Land use and land cover change as a result of human-induced transformations have contributed enormously to the deterioration of Ombeyi wetland. In this study, the magnitude of land use and land cover changes in Ombeyi wetland from 1990 to 2017 were quantified. Land cover changes have occurred in Ombeyi wetland over the study period. However, agriculture is still the main type of land use leading to increased surface runoffs, erosion, flooding, and sedimentation. The findings also depict that poverty levels coupled with the level of education significantly affected the land use and land cover dynamics in the study area. Similarly, the status of land cover and its dynamics have serious environmental and socio-economic implications at the local level and beyond. Appropriate tenable and effective land management strategies, guidelines and policies are urgently needed to avert undesirable land use and land cover changes taking place in Ombeyi wetland. Based on these results, the study recommends further studies to investigate the impact and consequences of these land use and land cover changes on the riparian rural livelihoods of the studied area so that landscape management decisions are made based on the scientific finding.

\section{Authors Contribution}

O.N.O is the lead author. He designed the research, analyzed the data and wrote the original draft paper. P.T.O. and G.G. supervised, reviewed and edited the work.

\section{Conflict of interest}


"The author(s) declare(s) that there is no conflict of interest regarding the publication of this paper."

\section{Funding Statement}

This research was funded by contributions from the author, friends and family members as part of his Master's thesis.

\section{References}

Ajwang, O. R., Kitaka, N., \& Omondi, O.S. (2016). Assessment of provisioning and cultural ecosystem services in natural wetlands and rice fields in Kano floodplain, Kenya. Ecosystem Services, 21, 166-173. https://doi.org/10.1016/j.ecoser.2016.08.008

Amsalu, A., Stroosnijder, L., \& De Graaff, J. (2007). Long-term dynamics in land resource use and the driving forces in the Beressa watershed, highlands of Ethiopia. Journal of Environmental Management, 83(4), 448-459. https://doi.org/10.1016/j.jenvman.2006.04.010

Andere, L. A. (2016). Spatial-temporal changes of landcover types in response to anthropogenic dynamics in Yala swamp, Kenya (Master's thesis, Kenyatta University, Nairobi, 7Kenya). Retrieved from http:///ir-library.ku.ac.ke/bitstream/handle/123456789/14945/Spatial temporal changes of landcover types in.pdf?sequence $=1$

Anderson, J. R. (1976). A Land Use and Land Cover Classification System for Use with Remote Sensor Data: Geological Survey Professional Paper 964; US Government Printing Office: Washington, DC, USA.

Appiah, D., Forkuo, E., Bugri, J., \& Apreku, T. (2017). Geospatial Analysis of Land Use and Land Cover Transitions from 1986-2014 in a Peri-Urban Ghana. Geosciences, 7(4), 125. https://doi.org/10.3390/geosciences7040125

Ariti, A. T., Van Vliet, J., \& Verburg, P. H. (2015). Land-use and land-cover changes in the Central Rift Valley of Ethiopia: Assessment of perception and adaptation of stakeholders. Applied Geography, 65, 28-37. https://doi.org/10.1016/j.apgeog.2015.10.002

Bassi, N., Kumar, M. D., Sharma, A., \& Pardha-Saradhi, P. (2014). Status of wetlands in India: A review of extent, ecosystem benefits, threats and management strategies. Journal of Hydrology: Regional Studies, 2, 1-19. https://doi.org/10.1016/j.ejrh.2014.07.001

Bewket, W. (2002). Land cover dynamics since the 1950s in Chemoga watershed, Blue Nile basin, Ethiopia. Mountain Research and Development, 22(3), 263-270. https://doi.org/10.1659/0276-4741(2002)022[0263:LCDSTI]2.0.CO;2

Bryan, E., Ringler, C., Okoba, B., Roncoli, C., Silvestri, S., \& Herrero, M. (2013). Adapting agriculture to climate change in Kenya: Household strategies and determinants. Journal of Environmental Management, 114, 26-35. https://doi.org/10.1016/j.jenvman.2012.10.036

Campbell, D. J., Lusch, D. P., Smucker, T. A., \& Wangui, E. E. (2003). Root causes of land use change in the Loitokitok Area, Kajiado District, Kenya. 
Cheruto, M. C., Kauti, M. K., Kisangau, P. D., \& Kariuki, P. (2016). Assessment of Land Use and Land Cover Change Using GIS and Remote Sensing Techniques: A Case Study of Makueni County, Kenya. Journal of Remote Sensing \& GIS, 05(04). doi:10.4172/2469-4134.1000175

Congalton, R. G., \& Green, K. (2002). Assessing the accuracy of remotely sensed data: principles and practices. CRC press.

Coppin, P., Jonckheere, I., Nackaerts, K., Muys, B., \& Lambin, E. (2004). Review ArticleDigital change detection methods in ecosystem monitoring: a review. International journal of remote sensing, 25(9), 1565-1596. https://doi.org/10.1080/0143116031000101675

DeFries, R., \& Eshleman, K. N. (2004). Land-use change and hydrologic processes: a major focus for the future. Hydrological processes, 18(11), 2183-2186. https://doi.org/10.1002/hyp.5584

Dessie, G., \& Kleman, J. (2007). Pattern and magnitude of deforestation in the South Central Rift Valley Region of Ethiopia. Mountain research and development, 27(2), 162-169. https://doi.org/10.1579/0044-7447(2008)37[263:fdaici]2.0.co;2

Foley, J. A., DeFries, R., Asner, G. P., Barford, C., Bonan, G., Carpenter, S. R., ... \& Helkowski, J. H. (2005). Global consequences of land use. science, 309(5734), 570-574. DOI: $10.1126 /$ science. 1111772

Geist, H. J.; Lambin, E. F. What Drives Tropical Deforestation? A Meta-Analysis of Proximate and Underlying Causes of Deforestation Based on Subnational Case Study Evidence; LUCC Report Series no. 4; LUCC International Project Office: Louvain-la-Neuve, Belgium, 2001.

Haller, T., Galvin, M., Meroka, P., Alca, J., \& Alvarez, A. (2008). Who gains from community conservation? Intended and unintended costs and benefits of participative approaches in Peru and Tanzania. The Journal of Environment \& Development, 17(2), 118-144. https://doi.org/10.1177\%2F1070496508316853

Harris, P. M., \& Ventura, S. J. (1995). The integration of geographic data with remotely sensed imagery to improve classification in an urban area. Photogrammetric engineering and remote sensing, 61(8), 993-998.

Hsieh, H. \& Shannon, S.E. Three approaches to qualitative content analysis. Qual. Res. 2005, 15, 1277-1288. https://doi.org/10.1177\%2F1049732305276687

Jan, P. L., Peter, H. V., Steven, J. S. (2005). Statistical Methods for Analyzing the Spatial Dimension of Changes in Land Use and Farming Systems; LUCC Report Series 7; International Livestock Research Institute: Nairobi, Kenya.

Jensen, J. R. (2015). Introductory digital image processing: a remote sensing perspective. Prentice Hall Press.

Kabumbuli, R., and Kiwazi W.F. (2009). Participatory planning, management and alternative 
livelihoods for poor wetland-dependent communities in Kampala, Uganda. African Journal of Ecology, 47(1), 154-160. https://doi.org/10.1111/j.1365-2028.2008.01063.x

Kairu, J. K. (2001). Wetland use and impact on Lake Victoria, Kenya region. Lakes and Reservoirs: Research and Management, 6(2), 117-125. https://doi.org/10.1046/j.1440-1770.2001.00135.x

Khisa, P. S., Uhlenbrook, S., van Dam, A. A., Wenninger, J., Van Griensven, A., \& Abira M., (2013). Ecohydrological characterization of the Nyando wetland, Lake Victoria, Kenya: A State of System (SoS) analysis. African Journal of Environmental Science and Technology, 7 (6), 417-434. http://dx.doi.org/10.5897/AJEST13.1426

Kiggundu, N., Anaba, L. A., Banadda, N., Wanyama, J., \& Kabenge, I. (2017). Assessing Land Use and Land Cover Changes in the Murchison Bay Catchment of Lake Victoria Basin in Uganda. Journal of Sustainable Development, 11(1), 44. https://doi.org/10.5539/jsd.v11n1p44

Kinaro, Z. (2008). Wetland Conversion to large-scale agricultural production; implications on the livelihoods of rural communities, Yala Swamp, Lake Victoria basin, Kenya.

Kindu, M., Schneider, T., Teketay, D., \& Knoke, T. (2013). Land use/land cover change analysis using object-based classification approach in Munessa-Shashemene landscape of the Ethiopian highlands. Remote Sensing, 5(5), 2411-2435. https://doi.org/10.3390/rs5052411

KNBS (1990), Kenya National Bureau of Statistics

KNBS (2000), Kenya National Bureau of Statistics

KNBS (2010), Kenya National Bureau of Statistics

Lesschen, J. P., Verburg, P. H., \& Staal, S. J. (2005). Statistical methods for analysing the spatial dimension of changes in land use and farming systems. Kenya: International Livestock Research Institute.

Li, X., Wang, Y., Li, J., \& Lei, B. (2016). Physical and socioeconomic driving forces of land-use and land-cover changes: A case study of Wuhan City, China. Discrete Dynamics in Nature and Society, 2016. doi:10.1155/2016/8061069

López, S. M. (2002). Papyrus Conservation around Lake Naivasha.

Manandhar, R., Odeh, I., \& Ancev, T. (2009). Improving the accuracy of land use and land cover classification of Landsat data using post-classification enhancement. Remote Sensing, 1(3), 330-344. https://doi.org/10.3390/rs1030330

Masek, J. G., Lindsay, F. E., \& Goward, S. N. (2000). Dynamics of urban growth in the Washington DC metropolitan area, 1973-1996, from Landsat observations. International Journal of Remote Sensing, 21(18), 3473-3486. https://doi.org/10.1080/014311600750037507

Maurice O. O., Victor A.O. Odenyo \& Faith N. K., (2017). The implications of Land Useand Land Cover Dynamics on Environmental Quality of Nairobi City, Kenya, American Journal 
$\begin{array}{llll}\text { of Geographic } \quad \text { Information } & \text { System, } & \text { 111-127. }\end{array}$

https://doi.org/10.5923/j.ajgis.20170603.04

Meyer, W. B., \& Turner, B. L. II. (1994). Changes in Land Use and Land Cover: A Global Perspective. Cambridge: Cambridge University Press. https://doi.org/10.1177\%2F030913339501900318

Mugenda, O. M., \& Mugenda. A. G. (1999). Research methods. Quantitative and qualitative approaches (pp. 46-48). Nairobi, Kenya: ACTS Press.

Munthali, M. G., Davis, N., Adeola, A. M., Botai, J. O., Kamwi, J. M., Chisale, H. L., \& Orimoogunje, O. O. (2019). Local Perception of Drivers of Land-Use and Land-Cover Change Dynamics across Dedza District, Central Malawi Region. Sustainability, 11(3), 832. https://doi.org/10.3390/su11030832

Mwagore D. (2002). Land use in Kenya-the case of a national land use policy. Land Reform, Kenya.

Mwakubo, S. M., \& Ikiara, M. M. (2005). Determinants of Papyrus Harvesting in the Yala Swamp, Kenya.

Opaa B. O., Okotto-Okotto J., Nyandiga C. O., \& Masese F. O. (2012). Nyando wetland in the future. In: Community based approach to the management of Nyando wetland, Lake Victoria Basin, Kenya, $1^{\text {st }}$ eds (eds P. O. Raburu, J. B. Okeyo Owuor \& F. Kwena) pp. 13242. Mcpowl Media Ltd, Kenya.

Osumba, J. J. L., Okeyo-Owuor, J. B., \& Raburu, P. O. (2010). Effect of harvesting on temporal papyrus (Cyperus papyrus) biomass regeneration potential among swamps in Winam Gulf wetlands of Lake Victoria Basin, Kenya.

Owino, A. O. \& Ryan, G. P. (2006). Recent papyrus swamp habitat loss and conservation implications in Western Kenya. Journal of Wetlands Ecology and Management, 15(1), 1-12.

Prakasam, C. (2010). Land use and land cover change detection through remote sensing approach: A case study of Kodaikanal taluk, Tamil Nadu. International Journal of Geomatics and Geosciences, 1(2), 150.

Raburu, P. O., Okeyo, J. B., Kwena, F. (2012). Community-Based Approach to the Management of Nyando Wetland, Lake Victoria Basin, Kenya.

Rawat, J. S., Biswas, V., \& Kumar, M. (2013). Changes in land use/cover using geospatial techniques: A case study of Ramnagar town area, district Nainital, Uttarakhand, India. The Egyptian Journal of Remote Sensing and Space Science, 16(1), 111-117. https://doi.org/10.1016/j.ejrs.2013.04.002

Schneider, L. C., \& Pontius Jr, R. G. (2001). Modeling land-use change in the Ipswich watershed, Massachusetts, USA. Agriculture, Ecosystems \& Environment, 85(1-3), 83-94. https://doi.org/10.1016/S0167-8809(01)00189-X

Serneels, S., \& Lambin, E. F. (2001). Proximate causes of land-use change in Narok District, 
Kenya: a spatial statistical model. Agriculture, Ecosystems \& Environment, 85(1-3), 65-81. https://doi.org/10.1016/S0167-8809(01)00188-8

Shiferaw, A., \& Singh, K. L. (2011). Evaluating the Land Use And Land Cover Dynamics In Borena Woreda South Wollo Highlands, Ethiopia. Ethiopian Journal of Business and Economics (The), 2(1).

Swallow, B., Onyango, L., \& Meinzen-Dick, R. (2003). Catchment Property Rights and the Case of Kenya's Nyando Basin'. Preparing for the Next Generation of Watershed Management Programmes and Projects, 123.

Tegene, B. (2002). Land-cover/land-use changes in the derekolli catchment of the South Welo Zone of Amhara Region, Ethiopia. Eastern Africa Social Science Research Review, 18(1), 1-20. https://doi.org/10.1353/eas.2002.0005

Terer, T., Ndiritu, G. G., \& Gichuki, N. N. (2004). Socio-economic values and traditional strategies of managing wetland resources in Lower Tana River, Kenya. Hydrobiologia, 527(1), 3-15. https://doi.org/10.1023/B:HYDR.0000043332.96368.c5

The Government of Kenya. (2014). Sessional Paper on National Wetlands Conservation and Management.

Torell, E., Crawford, B., Kotowicz, D., Herrera, M. D., \& Tobey, J. (2010). Moderating our expectations on livelihoods in ICM: Experiences from Thailand, Nicaragua, and Tanzania. Coastal Management, 38(3), 216-237. https://doi.org/10.1080/08920753.2010.483166

Turner, B. L., Lambin, E. F., \& Reenberg, A. (2007). The emergence of land change science for global environmental change and sustainability. Proceedings of the National Academy of Sciences, 104(52), 20666-20671.

Turner, K., (1991). Economics and Wetland Management. Ambio, 20, (2): 59-63.

Van der Knaap, M., Ntiba M. J. \& Cowx I. G. (2002). Key elements of fisheries management on Lake Victoria. Aquatic Ecosystem Health \& Management, 5(3), 245-254. https://doi.org/10.1080/14634980290031947

Wondie, M., Schneider, W., Melesse, A. M., \& Teketay, D. (2011). Spatial and temporal land cover changes in the Simen Mountains National Park, a world heritage site in Northwestern Ethiopia. Remote Sensing, 3(4), 752-766. https://doi.org/10.3390/rs3040752

World Bank. (2015). Ombeyi integrated wetland management plan. Kenya; s.n.http://documents.worldbank.org/curated/en/955041467980513750/Ombeyiintegrated-wetl and-management-plan.

Yuan, F., Sawaya, K. E., Loeffelholz, B. C., \& Bauer, M. E. (2005). Land cover classification and change analysis of the Twin Cities (Minnesota) Metropolitan Area by multitemporal Landsat remote sensing. Remote sensing of Environment, 98(2-3), 317-328. https://doi.org/10.1016/j.rse.2005.08.006 


\section{Copyright Disclaimer}

Copyright for this article is retained by the author(s), with first publication rights granted to the journal.

This is an open-access article distributed under the terms and conditions of the Creative Commons Attribution license (http://creativecommons.org/licenses/by/3.0/). 